Wulandari et al./ Factors Influencing Hyperuricemia

\title{
Factors Influencing Hyperuricemia: Evidence from Sukoharjo, Central Java, Indonesia
}

\author{
Dewi Wulandari \\ Graduate Program in Nursing, School of Health Sciences Mitra Husada, Karanganyar
}

\begin{abstract}
Background: Hyperuricemia is an elevated serum uric acid level. It causes urate deposits in the joints, tendons, and other tissues as physiological prerequisites for gout. Hyperuricemia is also related to the existence and severity of several comorbidities, such as hypertension, cardiovascular disease, diabetes, and metabolic syndrome. The result of basic health research in 2018 showed that the prevalence of joint disease in Indonesia based on a doctor's diagnosis was $7.3 \%$. The highest prevalence was in Aceh (13.3\%). The lowest prevalence was in West Sulawesi (3.2\%). This study aimed to examine factors associated with hyperuricemia.

Subjects and Method: This was an analytical observational study with a case control design. The study was conducted in Sukoharjo, Central Java, from January to April, 2018. A sample of 90 study subjects was selected by consecutive sampling. The dependent variable was hyperuricemia. The independent variables were age, sex, stress, purine-rich foods intake, and family history of gout. Stress was measured by depression, anxiety, and stress scale (DASS 42). The other variables were collected by questionnaire. The data were analyzed by a multiple logistic regression.

Results: Older age $(\mathrm{OR}=13.80 ; 95 \% \mathrm{CI}=3.36$ to $56.66 ; \mathrm{p}<0.001)$, female $(\mathrm{OR}=1.94 ; 95 \% \mathrm{CI}=3.36$ to $7.62 ; \mathrm{p}=0.345)$, purine-rich foods intake $(\mathrm{OR}=5.01 ; 95 \% \mathrm{CI}=1.48$ to $16.97 ; \mathrm{p}=0.010)$, and stress $(\mathrm{OR}=6.14 ; 95 \% \mathrm{CI}=1.83$ to $20.60 ; \mathrm{p}=0.003)$ increased the risk of hyperuricemia. Family history of gout $(\mathrm{OR}=1.47 ; 95 \% \mathrm{CI}=0.43$ to $5.04 ; \mathrm{p}=0.537)$ increased the risk of hyperuricemia, but it was statistically non-significant.
\end{abstract}

Conclusion: Age, female, purine-rich foods intake, and stress increase the risk of hyperuricemia. Family history of gout increases the risk of hyperuricemia, but it was statistically non-significant.

Keywords: hyperuricemia, purine-rich food, stress

\section{Correspondence:}

Dewi Wulandari. School of Health Sciences Mitra Husada. Jl. Ahmad Yani 167, Gapura Papahan Indah, Papahan, Tasikmadu, Karanganyar 57722, Central Java. Email: mujahidfiisabiilillah@gmail.com. Mobile: 089695098491.

\section{BACKGROUND}

Uric acid is the final product of purine metabolism in humans. The normal reference of uric acid in human blood is 1.5-6 $\mathrm{mg} / \mathrm{dL}$ in women and $2.5-7 \mathrm{mg} / \mathrm{dL}$ in men (Wardhana, 2018). Hyperuricemia is defined as an elevated serum uric acid level which. It causes urate deposits in the joints, tendons, and other tissues as physiological prerequisites for gout. Hyperuricemia is also associated with the existence and severity of several co-morbidities, such as hypertension, cardiovascular disease, diabe- tes, dyslipidemia, chronic kidney disease, atrial fibrillation, and metabolic syndrome (Ichida et al., 2012; Maruhashi et al., 2018). Hyperuricemia can occur due to increased uric acid metabolism (over production), decreased uric acid excretion (under excretion), or a combination of them (Kurniari, 2011)

Hyperuricemia is very common in developed countries. Based on the result of the National Health and Nutrition Examination Survey (NHANES), around 21\% (or 43 million) American adults aged 20 
years and above experienced hyperuricemia. Compared to developed countries, the prevalence of hyperuricemia tends to be lower in developing countries. For example, the prevalence of hyperuricemia was $10.6 \%$ in Thailand and 8.4\% in Saudi Arabia (Song et al., 2018). A recent meta-analysis of 36 articles from 2000 to 2014 showed that the prevalence of hyperuricemia in Mainland China was $13.3 \%$, while in Tibet China reached 37.2\% (Zhang et al., 2018).

The prevalence of hyperuricemia in Indonesia is still unclear. The prevalence of hyperuricemia in residents of Central Java was $24.3 \%$ in men and $11.7 \%$ in women. Based on a preliminary study of hyperuricemia in Sembiran Village, Bali Province, the prevalence of hyperuricemia was $18.9 \%$. Meanwhile, based on a field study, the prevalence of hyperuricemia in residents of Denpasar city was $\mathbf{1 8 . 2 \%}$. In addition, the prevalence of hyperuricemia in residents of Nusa Ceningan, Nusa Penida District, was $17 \%$. Based on a study conducted in rural tourism areas in Ubud District, the prevalence of hyperuricemia was $12 \%$ (Kurniari, 2011).

Based on the result of the Basic Health Research (Ministry of Health RI, 2018), the prevalence of joint disease in Indonesia, based on a doctor's diagnosis was $7.3 \%$. The highest prevalence was in Aceh (13.3\%) and the lowest was in West Sulawesi (3.2\%). The prevalence of joint disease at the age of 15 -24 years was $1.2 \%$; 25-34 years was $3.1 \%$; 35-44 years was $6.3 \%$; $45-54$ years was $11.1 \%$; $55-64$ years was $15.5 \%$; $65-74$ years was $18.6 \%$; and 75 years and above was $18.9 \%$. The prevalence of joint disease in women was $8.5 \%$; in men was $6.1 \%$; in urban residents was $6.9 \%$ and in rural residents was $7.8 \%$. The highest prevalence occurred in farmers, which was 9.90.
Hyperuricemia is affected by several factors, including sex, BMI (Body Mass Index), purine intake, and carbohydrate intake (Setyoningsih, 2009). Factors associated to the suspected occurrence of hyperuricemia are family history, obesity, fructose intake, purine intake, and fluid intake (Khoirina, 2016). Based on a study conducted by Diantari in 2012, purine intake affects uric acid level; however, fluid did not affect uric acid level in women aged 5060 years.

Based on a study conducted in Tibet, China, the characteristics associated with hyperuricemia were farmer $(\mathrm{OR}=1.75 ; 95 \%$ $\mathrm{CI}=1.02$ to 2.99), low education level (OR= $1.57,95 \% \mathrm{CI}=1.10$ to 2.24 ), alcohol consumption $(\mathrm{OR}=1.80 ; 95 \% \mathrm{CI}=1.19$ to 2.70$)$, hypertension $(\mathrm{OR}=1.48 ; 95 \% \mathrm{CI}=1.09$ to 2.01), $\mathrm{BMI}(\mathrm{OR}=1.12 ; 95 \% \mathrm{CI}=1.08$ to 1.16$)$ and serum creatinine $(\mathrm{OR}=1.05 ; 95 \% \mathrm{CI}=$ 1.03 to 1.06) (Zhang et al., 2018).

Based on a study conducted by Song et al., in 2018, hyperuricemia was more common in men than women $(7.9 \%$ vs. 4.9\%). The risk of hyperuricemia increased in both sexes as getting older. Men who consumed alcohol, had obesity, and had dyslipidemia were positively associated with hyperuricemia. Besides, single men and men who lived in North China had lower chance of having hyperuricemia. Women or single women at a higher economic level who lived in Southwest China, who smoke, had obesity, had diabetes, had hypertension, and had dyslipidemia were significantly associated with the risk factors of hyperuricemia. Women who lived in North China and North-West China had lower prevalence of hyperuricemia than women in East China. According to demographic, socio-economic, and geographical factors, the prevalence of hyperuricemia in China varies greatly. 
Wulandari et al./ Factors Influencing Hyperuricemia

This study aimed to analyze the factors influencing hyperuricemia.

SUBJECTS AND METHOD

\section{Study Design}

This was an observational analytic study with a case control design. The study was conducted in Sukoharjo, Central Java, from January to April 2018.

\section{Study Sample}

A sample of 90 study subjects was selected for this study by consecutive sampling.

\section{Study Variables}

The dependent variable was hyperuricemia. The independent variables were age, sex, family history of gout, stress, and purinerich foods intake.

\section{Study Instrument}

Data on stress was measured by Depression, Anxiety, and Stress Scale (DASS 42) questionnaire. Purine level was measured by uric acid meter.

\section{Data analysis}

This study was analyzed using univariate, bivariate, and a multiple logistic regression.

RESULTS
1. Sample characteristics
The characteristics of the study subjects can
be seen in Table 1.

Table 1. The distribution of study subjects of factors influencing hyperuricemia

\begin{tabular}{lcccc}
\hline \multirow{2}{*}{ Characteristics } & \multicolumn{2}{c}{ Case } & \multicolumn{2}{c}{ Control } \\
\cline { 2 - 4 } Age & N & \% & N & \% \\
$40-70$ years & & & & \\
$20-39$ years & 41 & 91 & 19 & 42 \\
Sex & 4 & 9 & 26 & 58 \\
Male & 18 & 40 & 9 & 20 \\
Female & 27 & 60 & 36 & 80 \\
Family History of Gout & & & & \\
With history & 7 & 16 & 5 & 11 \\
Without history & 38 & 84 & 40 & 89 \\
Purine-Rich Foods Intake & & & & \\
High & 35 & 78 & 14 & 31 \\
Low & 10 & 22 & 31 & 69 \\
Stress & & & & \\
High & 31 & 69 & 11 & 24 \\
Low & 14 & 31 & 34 & 76 \\
\hline
\end{tabular}

Based on the characteristics of the study subjects, the majority of subjects in the case group (91\%) were 40-70 years of age, while in the control group (58\%) were 20 -39 years of age. The majority of subjects were female (60\% in the case group and $80 \%$ in the control group). Only a small number of subjects had family history of gout (16\% in the case group and $11 \%$ in the control group).

Most of the subjects in the case group (78\%) consumed purine-rich foods with high intensity. Meanwhile, most of the sub- jects in the control group (69\%) consumed purine-rich foods with low intensity. Most of the subjects in the case group (69\%) had high stress level. In addition, most of the subjects in the control group (76\%) had low stress level.

\section{Bivariate Analysis}

Table 2 shows that the results of the bivariate analysis of factors influencing hyperuricemia. Variable of family history of gout did not have any influence on hyperuricemia. Hyperuricemia increased with age $(\mathrm{OR}=14.03 ; 95 \% \mathrm{CI}=4.29$ to $45.87 ; \mathrm{p}$ 
Indonesian Journal of Medicine (2019), 4(4): 321-328

https://doi.org/10.26911/theijmed.2019.04.04.04

$<0.001)$, and female $(\mathrm{OR}=2.67 ; 95 \% \mathrm{CI}=$

1.04 to $6.85 ; \mathrm{p}=0.041)$.

Table 2. The result of the bivariate analysis of factors influencing hyperuricemia

\begin{tabular}{lcccc}
\hline \multirow{2}{*}{ Independent Variables } & \multirow{2}{*}{ OR } & \multicolumn{2}{c}{$\mathbf{9 5 \%}$ CI } & \multirow{2}{*}{ p } \\
\cline { 3 - 4 } & & Lower limit & Upper limit & \\
\hline Age & 14.03 & 4.29 & 45.87 & $<0.001$ \\
Sex (female) & 2.67 & 1.04 & 6.85 & 0.041 \\
Family History of Gout & 1.47 & 0.43 & 5.04 & 0.537 \\
Purine-rich foods intake & 7.75 & 3.01 & 19.93 & $<0.001$ \\
Stress & 6.84 & 2.71 & 17.31 & $<0.001$ \\
\hline
\end{tabular}

3. Multivariate Analysis

Table 3. The results of the multivariate analysis

\begin{tabular}{lcccc}
\hline \multirow{2}{*}{ Independent Variables } & \multirow{2}{*}{ OR } & \multicolumn{2}{c}{ 95\% CI } & \multirow{2}{*}{ p } \\
\cline { 3 - 4 } & & Lower limit & Upper limit & \\
\hline Age & 13.80 & 3.36 & 56.66 & $<0.001$ \\
Sex (female) & 1.94 & 0.49 & 7.62 & 0.345 \\
Purine-Rich Foods Intake & 5.01 & 1.48 & 16.97 & 0.010 \\
Stress & 6.14 & 1.83 & 20.60 & 0.003 \\
\hline
\end{tabular}

Table 3 showed the results of multivariate analysis. Table 3 showed that older age $(\mathrm{OR}=13.80 ; 95 \% \mathrm{CI}=3.36$ to $56.66 ; \mathrm{p}$ $<0.001)$, female $(\mathrm{OR}=1.94 ; 95 \% \mathrm{CI}=3.36$ to $7.62 ; \mathrm{p}=0.345$ ), purine-rich foods intake $(\mathrm{OR}=5.01 ; 95 \% \mathrm{CI}=1.48$ to $16.97 ; \mathrm{p}=$ 0.010), and stress $(\mathrm{OR}=6.14 ; 95 \% \mathrm{CI}=1.83$ to $20.60 ; p=0.003$ ) increased the risk of hyperuricemia. Family history of gout $(\mathrm{OR}=$ $1.47 ; 95 \% \mathrm{CI}=0.43$ to $5.04 ; \mathrm{p}=0.537)$ increased the risk of hyperuricemia, but it was statistically non-significant.

\section{DISCUSSION}

\section{The influence of age on hyperuri- cemia}

This study showed that age factor influenced hyperuricemia $(\mathrm{OR}=13.80$; $95 \% \mathrm{CI}=$ 3.36 to 56.66; $\mathrm{p}<0.001)$. People aged 40 years and above had higher risk for having hyperuricemia. This probably occurred because there was a decline in kidney function at the age of 40 years and above in the process of excretion of metabolic waste in the body. It was characterized by high levels of urea and creatinine. Other factors that cause uric acid level increases at $<40$ years of age are obesity, high blood pressure, abnormal blood cholesterol level, and men who are in the severity level of alcohol dependence (Choi et al., 2005). Based on the age spectrum, the risk factor of hyperuricemia in young adults (30-39 years) is hyperlipidemia; meanwhile, lifestyle and some clinical syndromes play an important role in the middle-aged people (40-59 yrs). Different risk factors between sexes in the middle age are the effects of alcohol consumption in men and the effects of menopause in women. Impaired kidney function and the use of diuretics are important factors in the elderly ( $\geq 60$ years) (Lin and Chou, 2000).

The result of this study is in line with a study conducted by Kapetanovic et al. (2018) reported that in women, hyperuricemia is correlated with high BMI $(r=0.38)$, age $(\mathrm{r}=0.20)$, systolic blood pressure $(\mathrm{r}=$ o.20), triglycerides $(\mathrm{r}=0.30)$, lower eGFR $(\mathrm{r}=-0.27)$, total cholesterol $(\mathrm{r}=0.18)$, ESR 
Wulandari et al./ Factors Influencing Hyperuricemia

$(\mathrm{r}=0.17)$, fasting blood sugar $(\mathrm{r}=0.13)$, and the occurrence of hypertension, CVD and diabetes $(\mathrm{p}<0.001)$. Other studies show that subjects with hyperuricemia have older age, BMI, SBP, DBP, TG, and FPG in men and women (Zheng et al., 2018).

Based on a study conducted by Setyoningsih (2009), age has a positive correlation with gout $(\mathrm{r}=0.85 ; \mathrm{p}<0.001)$. It means that the strength of correlation is moderate. The result of the linear regression analysis showed that each increase in 1 age score would increase 0.068 score of uric acid $(b=$ 0.104; $\mathrm{p}<0.001$ ).

\section{The influence of sex on hyper- uricemia}

Based on the result of this study, men had higher risk for having hyperuricemia $(\mathrm{OR}=$ $1.94 ; 95 \% \mathrm{CI}=3.36$ to $7.62 ; \mathrm{p}=0.345$ ). The uric acid level in men in the blood at puberty can reach $5.2 \mathrm{mg} / \mathrm{dl}$. It will increase with age because there is no estrogen hormone as uricosuric agent. It is a chemical that assists the excretion of uric acid through the kidney. The mechanism of uricosuric agent in uric acid excretion is to inhibit URAT1 (urate transporter-1) from the lumen to the proximal tubular cells when regulating electrolyte fluid balance (Setyoningsih, 2009).

The result of this study is in line with a study conducted by Billa et al. (2018), that there is a statistically significant correlation between sexes (male vs. female; $\mathrm{p}<0.0001$ ) and different age categories ( $<30$ years vs. 31-50 years); $\mathrm{p}=0.02 ; 31-50$ years vs. $>50$ years; $\mathrm{p}<0.0001$; $\leq 30$ years and $>50$ years; $\mathrm{p}<0.0001$; chi square test). It is related to the prevalence of $\mathrm{HU}$ in the overall population. A study conducted by Zhang et al. (2018), showed that the prevalence of hyperuricemia in men is higher than in women ( $41 \%$ vs. $34.4 \%, p=0.011$ ).

\section{The influence of family history of gout on hyperuricemia}

This study showed that family history of gout increased the risk of hyperuricemia $(\mathrm{OR}=1.47 ; 95 \% \mathrm{CI}=0.43$ to $5.04 ; \mathrm{p}=0.537)$. A study conducted by Kuo et al. (2015), states that the main risk factors of gout are hyperuricemia, genetics, dietary factors, drugs, comorbidities, and lead exposure.

Impaired uric acid excretion by the kidney is one of the causes of increased level of uric acid, hyperuricemia, and nephropathy. The kidney filters free circulating uric acid. It filters around $70 \%$ of the total uric acid excretion from the body. Based on a study conducted by Chittoor et al. (2017), all kidney urinary excretions were significantly inherited ( $\mathrm{p}<2 \times 10-6)$. Its range was from 0.41 to 0.74 . The empirical threshold value for genome area significance was set at $\mathrm{p}<1$ $\times 10-7$. There was a strong correlation $(\mathrm{p}<8$ $\times 10-8$ ) between uric acid excretion and single nucleotide polymorphism (SNP) in the 446 zinc finger protein (ZNF446) (rs2O33711 (A / G), MAF: 0.30). Minor alleles (G) were associated with increased uric acid clearance. The study also found a suggestive correlation between gout clearance and SNP in ZNF324, ZNF584, and ZNF132 (in the 72 $\mathrm{kb}$ area on $19 q 13$; $\mathrm{p}<1 \times 10-6$, MAFs: $0.28-$ 0.31). This study showed the importance of the $19 q 13$ area in regulation of uric acid excretion by the kidney in Hispanic children.

\section{The influence of stress on hyper- uricemia}

The result of the study showed that stress could increase the risk of hyperuricemia $(\mathrm{OR}=6.14 ; 95 \% \mathrm{CI}=1.83$ to $20.60 ; \mathrm{p}=$ 0.003). Psychological stress causes neuroendocrine, inflammatory, metabolic, and transcriptional disorders that tend to affect a disease (Picard et al., 2015). Acute stress disorder can affect the activity of the HPA axis (e.g. cortisol) and the sympathetic 
Indonesian Journal of Medicine (2019), 4(4): 321-328

https://doi.org/10.26911/theijmed.2019.04.04.04

nervous system (e.g. heart rate and blood pressure). Even though a greater acute autonomic response has been found in adult men, but women has showed increased sensitivity to the higher adrenal cortex (Murphy and Loria, 2017).

Gout is associated with mental health, but its nervous mechanism is still unclear (Goodman et al., 2016). Cortisol hormone production increase when stress occurs. Therefore, the metabolism of carbohydrates, fats, proteins, and purines also increases. Increased purine metabolism causes an increase in uric acid level in the blood. A study by Bobaya (2016), there is a correlation between stress and gout arthritis in Tobelo Community Health Center, Tobelo District, North Halmahera.

\section{5 . The influence of purine-rich foods intake on hyperuricemia}

This study showed that purine-rich foods intake could increase the risk of hyperuricemia $(\mathrm{OR}=5.01 ; 95 \% \mathrm{CI}=1.48$ to 16.97 ; $\mathrm{p}=$ o.010). Some purine-rich foods such as liver, intestine, red meat, sardines are often consumed by subjects in the case group. Besides, foods with low purine such as tofu, tempeh, and long beans are more often consumed by subjects in the control group. The content and bioavailability of purines in food ingredients varies. Besides, the change of purines to uric acid also depends on the relative cellularity and the transcription and cellular metabolic activity of the food. Transcription activity is the ability of cells to interpret the genetic code of one type of nucleic acid into another form. In this case, cells are able to convert purines in food into uric acid. Purines derived from animal source foods have high level of bioavailability. Besides, the amount of animal source foods is also high. Most of exogenous purines, which are derived from food, will be directly converted to uric acid without the occurrence of tissue nucleic acids. However, guanine, hypoxanthine, and exogenous xanthine which do not combine into nucleic acids will rupture and form uric acid with the guanase enzymes assistance and oxidant xanthine in the intestinal epithelium (Choi and Curhan, 2004).

A study by Kusumayanti et al. (2015), the patterns of purine consumption and obesity had significant differences. The sequence of risk factors of hyperuricemia was obesity (OR = 2.32; 95\% CI: 1.13-4.75); frequency of rich-purine foods consumption $(\mathrm{OR}=2.16$; 95\% CI: 1.06 to 4.00); level of purine consumption $(\mathrm{OR}=2.14 ; 95 \% \mathrm{CI}=$ 1.02 to 4.48); and types of rich-purine foods consumed $(\mathrm{OR}=2.12 ; 95 \% \mathrm{CI}=1.05$ to 4.28).

A study conducted by Setyoningsih in 2009, variable of high-purine diet had a positive correlation on uric acid levels $(\mathrm{r}=$ $0.82 ; \mathrm{p}<0.001)$. The result of linear regression analysis showed that each increase in 1 high-purine diet score would increase 0.264 scores of uric acid (95\% CI= 0.14 to $0.39 ; \mathrm{p}$ $<0.001)$.

6. The influence of age, sex, high purine food intake, and stress on hyperuricemia

The effect of age between men and women on hyperuricemia is different. At the productive age, men have a higher risk of hyperuricemia than women. After menopause, women have a higher risk of hyperuricemia than men (Song et al., 2018). This is likely related to the loss of uricosuric estrogen after menopause (Kuo et al., 2015). In other words, the difference in the prevalence of hyperuricemia in both sexes seems to be narrow as getting older. However, hyperuricemia is still a male-dominated disease as shown in several studies.

AUTHOR CONTRIBUTIONS

Dewi Wulandari collected the data on age, 
Wulandari et al./ Factors Influencing Hyperuricemia

sex, stress, family history of gout, and uricemia level, did the data analysis, interpreted the results of data analysis, and wrote the manuscript.

\section{CONFLICT OF INTEREST}

We declare that we do not have any conflict of interest.

FUNDING AND SPONSORSHIP

There is no external fund and sponsorship.

\section{ACKNOWLEDGEMENT}

We would like to thank to the Sukoharjo District Health Office, for giving permission to collect the data to this study.

\begin{tabular}{l}
\hline REFERENCE \\
\hline Billa G, Dargad R, Mehta A (2018). Original \\
article prevalence of hyperuricemia in \\
indian subjects attending hyperuri- \\
cemia screening programs-A Retro- \\
spective Study. 66(4): $43-46$.
\end{tabular}

Bobaya P (2016). Hubungan tingkat stres dengan kejadian gout artritis di puskesmas Tobelo Kecamatan Tobelo Kabupaten Halmahera Utara. E-jurnal Keperawatan, 4(1).

Chittoor G, Haack K, Mehta NR, Laston S, Cole SA, Comuzzie AG, Butte NF, Voruganti VS (2017). Genetic variation underlying renal uric acid excretion in Hispanic children: The viva la familia study. BMC Medical Genetics. BMC Medical Genetics, 18(6): 1-8. doi: 10.1186/s12881-016-0366-3.

Choi HK, Curhan G (2004). Beer, liquor, and wine consumption and serum uric acid level: The Third national health. Arthritis \& Rheumatism (Arthritis Care \& Research), 51(6): 10231029. doi: 10.1002/art.20821.

Choi HK, Liu S, Curhan G (2005). Intake of purine-rich foods, protein, and dairy products and relationship to serum levels of uric acid the Third National Health and Nutrition Examination Survey. Arthritis \& Rheumatism, 52(1): 283-289. doi: 10.1002/art.20761.

Diantari E (2012). Pengaruh asupan purin dan cairan terhadap kadar asam urat pada wanita usia 50-60 Tahun di Kecamatan Gajah Mungkur, Semarang. Program Studi Ilmu Gizi Fakultas Kedokteran Universitas Diponegoro. doi: 10.1016/S1387-2656(oo)05035-3.

Ichida K, Matsuo H, Takada T, Nakayama A, Murakami K, Shimizu T, Yamanashi T, Kasuga H (2012). Decreased extrarenal urate excretion is a common cause of hyperuricemia. Nature Communications. Nature Publishing Group. 3: 764-767. doi: 10.1038/ncomms1756.

Kapetanovic MC, Nilsson PM, Turesson C, Dalbeth N, Englund M, Scheepers LEJM, Jacobsson LTH (2018). Predictors for clinically diagnosed gout: 30 years' follow-up in the Malmo Preventive Project cohort Sweden. Scandinavian Journal of Rheumatology. Arthritis Research \& Therapy, 47(129): 25-26. doi: http://dx.doi.org/10.1080/03009742.2018.1487639.

Kementrian kesehatan RI (2018). Hasil utama riskesdas 2018.

Khoirina A (2016). Faktor-faktor yang berhubungan dengan kejadian terduga hiperurisemia pada pralansia di Pos Pembinaan Terpadu (Posbindu) wilayah kerja puskesmas pamulang Tahun 2016. UIN Syarif Hidayatullah Jakarta: Fakultas Kedokteran dan Ilmu Kesehatan. Available at: http://repository.uinjkt.ac.id/dspace/handle/12$3456789 / 37218$.

Kuo C, et al. (2015). Global epidemiology of 
gout: Prevalence, incidence, and risk factors. Nature Reviews Rheumatology. 11: 649-662.

Kurniari PK (2011). Hubungan hiperurisemia dan fraction uric acid clearance. Jurnal penyakit dalam, 12: 77-80. Available at: http://download.portalgaruda.org/article.php?article $=13227$ \&val $=927$.

Kusumayanti GAD, Wiardani NK, Antarini AAN (2015). Pola konsumsi purin dan kegemukan sebagai faktor risiko hiperurisemia pada masyarakat Kota Denpasar. Jurnal Skala Husada, 12(1): 27-31.

Lin $\mathrm{K}$, Lin $\mathrm{H}$, Chou $\mathrm{P}$ (2000). The interaction between uric acid level and other risk factors on the development of gout among asymptomatic hyperuricemic men in a prospective study. The Journal of Rheumatology, 27(6): 1501-1505.

M.Goodman A, Wheelock MD, Harnett NG, Mrug S, Granger DA, Knight DC (2016). The hippocampal response to psychosocial stress varies with salivary uric acid level. Neuroscience, 339: 396-401.

Maruhashi T, Hisatome I, Kihara Y, Higashi Y (2018). Hyperuricemia and endothelial function: From molecular background to clinical perspectives. Atherosclerosis. Elsevier, 278: 226231. doi: 10.1016/j.atherosclerosis.2018.10.007.

Murphy MO, Loria AS (2017). Sex-specific effects of stress on metabolic and cardiovascular disease: are women at higher risk?. Am J Physiol Regul Integr Comp Physiol 313: 1-9. doi: 10.1152/ajpregu.00185.2016.
Picard M, McManus MJ, Gray JD, Nasca C, Moffat C, Kopinski PK, Seifert EL, McEwen BS, Wallace DC (2015). Mitochondrial functions modulate neuroendocrine, metabolic, inflammatory, and transcriptional responses to acute psychological stress. PNAS. 112 (48) E6614-E6623. doi: 10.1073/pnas.1515733112.

Setyoningsih R (2009). Kejadian hiperurisemia pada pasien rawat jalan RSUP Dr. Kariadi Semarang Program Studi S1 Ilmu Gizi Fakultas Kedokteran Universitas Diponegoro.

Song P, Wang H, Xia W, Chang X, Wang M, An L (2018). Prevalence and correlates of hyperuricemia in the middleaged and older adults in China. Scientific Reports. Springer US, 8(1): 19. doi: 10.1038/s41598-018-22570-9.

Wardhana AR (2018). Effect of uric acid on blood glucose levels. Acta Med Indones - Indones J Intern Med, 50(3): 253-256.

Zhang X, Meng Q, Feng J, Liao H, Shi R, Shi D, Renqian L, Langtai Z, Diao Y, Chen $X$ (2018). The prevalence of hyperuricemia and its correlates in Ganzi Tibetan Autonomous Prefecture, Sichuan Province, China. Lipids in health and disease. 17(1): 235. doi: 10.1186/s12944-018-0882-6.

Zheng X, Wei Q, Long J, Gong L, Chen H, Luo R, Ren W, Wang Y (2018). Gender-specific association of serum uric acid levels and cardio-ankle vascular index in Chinese adults. Lipids in Health and Disease. Lipids in Health and Disease, 17(1): 1-6. doi: 10.1186/s12944-018-0712-x. 